Article

\title{
Goal-Oriented Ethics: Framing the Goal-Setting Concretely
}

\author{
Mathew Illathuparampil \\ Department of Christian Ethics, St. Joseph Pontifical Seminary, Aluva 683102, India; \\ illathuparampilmathew@gmail.com
}

Received: 17 August 2017; Accepted: 7 October 2017; Published: 17 October 2017

\begin{abstract}
Joseph Selling, professor emeritus from KU Leuven, Belgium, recently made a significant contribution towards ethical methodology. It is in fact a continuation of the in-house conversations that have been in vogue about methods in moral reasoning since Vatican II in the discipline called theological ethics. What is specific about Selling's attempt is that he re-orients or reframes the evaluation of the moral event to consider human intentionality or motivation before considering human behavior or human acts. He convincingly establishes his method by a meticulous reading of Thomas Aquinas. This paper is a response to the goal-oriented ethics that he has posited. As illustrated below, this paper evaluates the goal-oriented approach as solid and sufficient. While fully endorsing this approach, this paper argues that the process of ethical goal-setting is to be framed concretely. In a concrete historical context, so that a goal-oriented approach fully serves its purpose, this paper proposes that it is to be reinforced by four supportive pillars, which are in fact assumed by Selling in his work. They are openness to human sciences, conversation among various narratives, positing a theological frame for ethical reasoning, and recourse to non-discursive reasoning.
\end{abstract}

Keywords: ethical methodology; Joseph Selling; goal-oriented approach; non-discursive reasoning; narratives

\section{Introduction}

Book-length discussions on ethical methodology are rather rare. Rarer still are proposals for reframing theological ethics. Joseph Selling, with his book Reframing Catholic Theological Ethics, (Selling 2016) has nevertheless travelled into that less trodden terrain. While it is a matter of great accomplishment for him, for the company of Christian ethicists, it poses a great task-to grasp, evaluate, and integrate the major claims that he makes in this work into contemporary ethical reasoning, particularly ethical methodology.

Selling reframes Catholic theological ethics by positing a goal-oriented approach to ethical thinking in the place of the traditionally held act-oriented approach. In the act-oriented approach, what a person does figures more prominently in the total moral event than what a person is or what she or he should become. He comes to this understanding by a meticulous reading of Thomas Aquinas. Thus, he is able to affirm: "If I had to single out one thing that characterizes Thomas' uniqueness in our Western, ethical tradition, it would have to be his insistence that the moral evaluation of human activity begins with the integrity of moral intention, which is subsequently followed by a consideration of behavioral options. Who one is, the moral character that the acing person exhibits, is by far more important than the sometimes clumsy, uninformed, or simply mistaken behavioral choices that we make" (Selling 2016, p. 82).

The end or circumstantiated intention becomes very crucial in the goal-oriented pattern of reasoning. As well argued in his work, the goals of ethical living are set over against three overarching points of reference. First, in traditional terms, virtues; second, according to Vatican II, in terms of human 
dignity; third, following the lead of Vatican II and as expounded by some ethicists, in terms of the paradigm of the human person adequately and integrally considered (Christie 1990; Janssens 1980).

What Selling graphically presents in the book could be summarily understood as a conceptual scheme in the sense of a systemic way or model for thinking about methodological issues in ethics. It is a way of organizing moral experience in a coherent way. It makes use of the traditional categories that give form to what he meaningfully calls a moral event (Selling 2016, p. 62). As an abstract working conceptual scheme, this is certainly closer to reality than the traditional act-centred model, historically, precast to help the confessors.

When someone wants to take his/her intention towards the goal of ethical living in regard to any of the three points of reference/standards, content-wise it ceases to be simple. For in itself, the process of ethical goal setting stomachs a sort of historical conditioning. This means that the overarching justifications/legitimations of ethical goal setting do not enjoy universalizability or wider communicability. First, let us consider the case of virtues. One can choose to realize cardinal virtues, or any other virtue, which we can imagine. But every (category of) virtue represents a historical, political, or even ideological life-world. To some degree, at least in certain cases, virtues reveal a sort of theological determination as well. For example, in spite of their historical affinity, the same virtues in the Greek city states and the Christian West did not have the exact same meanings. St. Ambrose and St. Augustine Christianized Greek virtues vary in their interpretation. Similarly, what is virtuous in medieval feudal society, for instance, freedom, would not be so in a modern democratic society.

Second, we consider human dignity. In spite of its wide political assertion through the concept of human rights, human dignity is subject to differing interpretation. For example, when Albert the Great defined a person as "a subject distinguished by dignity" he was in a way defining human identity in terms of human dignity. But Thomas does not go so far. He, for example, held that human beings could lose their dignity if they deviate from the rational order by sinning, and that it is not necessarily bad to kill such sinners, despite the fact that to kill an innocent person in possession of natural dignity is evil. Be it also remarked that Aquinas uses the phrase dignitas humana very rarely-in the Summa Theologiae only once (II-II 64,2). Perceptions of human dignity are in reality conditioned by different features of human reality: human nature; God-relatedness; the faculty of reason; or recognition within society. Depending on the interpretation of human dignity on account of the above parameters, one may choose different ethical approaches to female genital mutilation, experimentation with human subjects, punishments, human cloning, stem cell research, etc.

Third, let us turn quickly to the paradigm of the human person adequately and integrally considered. It gives due attention to the historicity of the human person. Nonetheless, the paradigm of the human person adequately and integrally considered may not be able to interpret or account for certain human goals and the concomitant intention and the subsequent behavior within that paradigm. For example, think about an ethical goal that involves a break from the integrity of the parameters of the human person adequately and integrally considered. Take, for instance, one's choice of martyrdom or ascetic life. Such instances are so radical that, for the sake of a particularly highly esteemed goal, one chooses to relinquish the essential parameters of the human person adequately and integrally considered. To illustrate this point further, when someone opts for martyrdom for the sake of a religious goal, $\mathrm{s} / \mathrm{he}$ is willing to surrender some of the parameters of the human person adequately and integrally considered, such as her/his corporeality, her/his being part of the material world, and her/his historicity. In this situation, the ethical goal or intention of the one who opted for martyrdom escapes the evaluative parameters of the human person adequately and integrally considered.

\section{Four Supportive Pillars}

Briefly, what I am trying to argue here is this: as an abstract methodological scheme, the legitimation for making a goal-oriented approach is solid and sufficient. While fully endorsing this approach, I believe that the process of ethical goal-setting is to be framed concretely. For goal 
setting does not float above historical and contingent realities from which we simply deduce values and norms. But in a concrete historical context, so that a goal-oriented approach serves its purpose, I propose that it is to be reinforced by four supportive pillars. They are mentioned in the book of Selling in various places. For example, when he describes "the virtuous person" he is circumspect enough to state that one is a very situated person (Selling 2016, p. 161). The kinds of virtue enlisted by him do not make any claim universal; rather, they are historically conditioned by elements such as geography, culture, and religion. But in this attempt, I shall capture, expand, and bring them into focus. This is one way in which we can ensure that ethical goal-setting is practically well-founded, drawing on human experience or a wider grasp of what it means to be human. We now turn to a thumbnail sketch of those four pillars.

\subsection{Openness to Human Sciences}

It is quite understandable that ethical reflections or conclusions are considerably informed by existing scientific knowledge about the human person and the world. Aristotelian or Thomistic ethics is not an exception to this rule. In the medieval period, ethics was backed more by philosophy and theology than by human sciences. Openness to human sciences such as biology, anthropology, psychology, sociology, and medicine will surely shed light on what it means to be human. Even the claims of equal human dignity for all men and women would not be possible without the support of science. Think about the past example: women were ill-treated considering them as "defective males," a tradition attributed to Aristotle, because of the ancient underdeveloped biology. On account of the then prevalent "scientific data" that woman "requires a smaller quantity of nutriment," it was customary in his society to allow girls and women to eat only half as much as boys and men (Aristotle 1965, 608b.14).

Openness to science has yet to become a parameter to determine our ethical goals. A good example would be the attempt to distinguish between homosexual acts and homosexual orientation. Openness to science has still to enlighten various aspects of ethical discourse in distinguishing between homosexual acts and homosexual orientation. Science can ascertain whether sexual orientation ranges along a continuum, from exclusive attraction to the opposite sex to exclusive attraction to the same sex, or whether homosexual acts can be explained scientifically in any other way. If ethical discussions do not depend on scientific data, they could be led by identity labels given to sexual behaviors by different cultures. A scientific indication of the moment of brain death becomes significant in regard to justifying organ harvesting from a cadaver. While admitting the role of science in making sound ethical discourse, we need to underline that science does not, nay cannot, adequately make value statements. Granted, there are still debatable claims made by "science," which have apparent ramifications for ethics. For example, the discussions regarding "criminal genes." Similarly, a "scientific" approach to selecting the beneficiaries of charity may not always satisfy certain ethical aspects. In spite of these reservations, openness to advancements in science is vital for keeping ethical goals in the right perspective. We may not need refer to science on a daily basis in setting our ethical goals. We presume it more often than not. But those who make ethical teachings need it very much.

\subsection{Conversation among Narratives}

Selling establishes convincingly and reiterates that, in a moral event, the first question is what one wants to accomplish. More precisely, it refers to the ethical goals. He acknowledges that each of us may choose different ways to accomplish what we may identify as virtues. In that process, he argues, persons are to be helped to construct a narrative that highlights virtuous living (Selling 2016, p. 197). Going a step further, let me propose that, to enrich the process of goal setting, we need a healthy interface of different narratives. Think about two prominent and closely related figures of the New Testament: John the Baptist and Jesus. Both had different behavioral patterns because both had different goals set-because both of them operated from two different narratives. The Baptist was following the prophetic narrative of the Old Testament, while Jesus was following and creating a 
narrative of the kingdom of God. One can say broadly that John the Baptist belonged to the prophetic narratives, which usually consist of warnings, condemnations, exhortations, advice, and eventually encouragement. They also often tended to announce curses. They insisted vehemently on the justice of God. But Jesus introduced a fairly different narrative of the kingdom of God where the mercy of God prevailed. Their narratives were so different that at one point John the Baptist was scandalized at the behavior of Jesus, and asked him, are you the promised one? (Mt 11:3).

Goal setting has to attend to the underlying narrative that persons carry about their different values, ideals, and virtues. For example, according to the narrative that one follows, one may oppose violence or engage in violence. Parenting, respect to life, respect to differences, conflict resolution, and a host of other vital concerns are driven by a certain kind of a narrative that persons follow, and accordingly they will have different ethical goals set for themselves.

In a multi-religious and pluri-cultural context, there must be occasions for one narrative to converse with, if not confront, another narrative. This has many implications, especially when ethics is done in the public square. In a country like India, for instance, when the Catholic Church argues against abortion in public, for many people it is simply unintelligible. For different parties in this conversation follow different narratives. For similar reasons, the work of Mother Theresa, in taking care of dying and sure-to-die persons, was not equally appreciated across the globe. Close exchange between the diverse narratives of people is mandatory to keep the ethical goals of people purified and intelligible to others.

What every culture does ultimately is the organization of human consciousness on a collective level. "What is religion if it is not a powerful agency for the organization of consciousness?" (Hefner 2003, p. 188). The values we hold, the moral judgements that we make, and the decisions that we take depend to a great extent on how our consciousness is organized (Hefner 2003, p. 187). Religion seeks to organize consciousness according to the deepest realities of life, the realities that relativize all others. It suggests that our perceptions of right/wrong and good/bad depend heavily on how our consciousness is organized by religious narratives.

Morality depends very much on how the community and narratives shape an individual. The rootedness of a person in a community of life and meaning inserts her/him into a narrative. Conversation among different narratives may ultimately require reference to a "grand narrative" (if we can use that expression and withstanding the critique of postmodernism) effective for goal-setting. Perhaps the best candidate for such a grand narrative would be the Kingdom of God, which again immediately falls into small narratives in practice. This leads us to the next step.

\subsection{Theological Frame for Ethical Goal Setting}

The ethical scheme proposed by Selling rightly focuses on what one wants to accomplishthe goals. From a goal follows the attitude and action within a given circumstance to realize that ethical goal. But choosing (or not choosing) a goal is closely related to the question of why one should choose that particular goal, which is likely to be demanding. That demanding part is usually expressed through commandments or norms.

In real situations, ethical goals are set within larger life goals. It could be something similar to this scenario: a person has many options of games, such as basketball, cricket, and football. Once s/he opts for a particular game, $\mathrm{s} /$ he is bound to follow its rules. But the important question is why does $\mathrm{s} /$ he choose that game? In a much similar way, a question would surface: why should one place him-/herself in the parameters of particular goals to become ethical? The answer to this question will go beyond the boundaries of ethics.

The traditional answer to this question is as straightforward as to go to heaven. The larger life goal that justifies an ethical goal is indicated in the question of the Pharisee, what good deed must I do to inherit eternal life? (Mt 19:16). Jesus in his turn makes a shift, saying "if you want to be perfect," follow the commandments. Jesus later embellishes it in relation to entering the Kingdom of God. This exchange of question and answer bears theological content. That reveals the scope of theological 
ethics, which brings out the motivational aspect of ethical goal setting. Ethics permeated by theology shall ineluctably result in better communicability in a faith community.

Vatican II in its document Optatam totius no. 16 wanted theological disciplines to make use of the Bible: "The students are to be formed with particular care in the study of the Bible, which ought to be, as it were, the soul of all theology. After a suitable introduction they are to be initiated carefully into the method of exegesis ... " Until the period of the Council, scriptures were used in ethics only in a proof-texting manner. After establishing their conclusions with the support of natural law and philosophy, ethicists used to refer to scriptural passages as an additional proof for their conclusions. They did so using the Bible quite literally. After the Council, there were many attempts to integrate scripture or theology into ethical reflections. It is interesting to note that more than forty years after Vatican II, the Vatican's Pontifical Biblical Commission issued a document in 2008 entitled: Bible and Morality: Biblical Roots of Christian Conduct. However, the integration of scripture into ethical reasoning is still due, which is also in view of a goal-oriented approach to ethics.

\subsection{Non-Discursive Reasoning}

A goal-oriented approach to ethics rightly recognizes the proportion between the goal and the means chosen and the inevitable scope of the evil tolerated. Circumstantiated intention presupposes a sort of calculation of the good achieved and the evil avoided or tolerated. Sometimes it can be a vague kind of calculation, for it need not always enjoy any sort of scientific or mathematical precision. It could better be called a perceptive evaluation of the good achieved and the evil avoided or tolerated. In the process of setting ethical goals, there is a rational calculation of the circumstance and material facts. For example, environmental protection has become part of our ethical goals thanks to the recent calculated prediction of the impact of environmental degradation on human life and the ecosystem. In determining the core demand of justice (what one owes to another), there is some sort of a rational evaluation of the claims to and fro. When a business corporation chooses to do its social responsibility by spending part of its profit, it involves a good amount of calculative reasoning. Briefly, ethical goal setting is usually supposed to be rational and calculative. In the scheme presented by Selling, this discursively rational overtone is clear. His conversation partners, including Thomas, followed this line. This is an indubitable part of goal setting.

In the process of setting goals, along with the discursive part, there is a complex structure of affections and judgements that are part of the goal that we set. Consciously or not, an affective affirmation (Farley 2011, p. 144) of what is set as the goal takes place. We do not just know the goal, but we experience being morally obliged. But we do not know exactly how we come to that experience of being morally obliged. A few attempts have been made to refer to that level of knowing: St. Augustine in his Confessions (9.9) said, "my love is my weight." Thomas seems to assume that principles of natural moral law break through into human consciousness (Summa Theologia II-II, 90, a.1 ad 1, q.91, a.2). In philosophy, David Hume spoke of "moral sentiments" as an inbuilt affective trigger (Hume 1968, III.2.5).

Ethical purposiveness, I believe, must also allow credence for the non-discursive epistemological elements, for humans are not only coming to know moral truths, but are also capturing them through non-discursive faculties. These would include a sense of fairness, moral imagination, discernment, intuitions, aesthetic perceptions of what is right and wrong, and a sense of the sublime, all of which escape deductive rational calculations. There are ethical goals chosen by people that in no way are explained by a simple discursive rationality. That means, in ethical goal setting, men and women are also guided by extra-discursive reasoning.

A moral approach, if it is to be relevant and applicable to situations and intentions of real human beings, cannot simply be governed by discursive reason alone, for human rationality is also comprised of non-discursive elements (Illathuparampil 2009, p. 150). Reason always seeks or establishes something to justify itself from outside. But human beings may set ethical goals even without reference to a justification from outside (rational ground). Rationality seeks to establish 
meaning or justification by a sort of "coherence of intersubjective relationships" (Gaziaux 2011, p. 132). There is no such thing as a discursive justification in poetry (poiesis). That is why Socrates said in Plato's Republic (607b), "there is from old a quarrel between philosophy and poetry." However, we do not condemn poetry as stupidity. It is no surprise that an ethical system that heavily drew from abstract philosophy became incapable of addressing non-discursive ways of knowing or judgements. In philosophical ethics, Kant represents the epitome of this approach. He sought to guarantee the autonomy of morality by grounding morality neither in religious or metaphysical beliefs, nor in any empirical account of humanity, but in rationality qua rationality. Thus, the feelings and the history of the agent are not at all taken into consideration. It assumes and even celebrates objectivity in moral life attained by freeing moral judgements from the subjective story of the agent.

When a goal-oriented moral approach is open to non-discursive style of reasoning, it would be able to accommodate apparently erratic moral elements in our ethical reasoning. For example, Adam Smith in his Theory of Moral Sentiments argued that, however selfish a person can be, there are principles in his nature that interest him in the fortune of others. One of these "principles" is sympathy ((Smith 1976, I.(I) 1.1)). Only a sort of moral imagination will allow you to hold that the most selfish person can also be sympathetic to others. No axiomatic-deductive system will be able to perceive this complex human trait.

\section{Conclusions}

Sustained discussions on ethical methodology require a great amount of familiarity with technical terms and the history of the development of theological ethics. Reframing of Catholic theological ethics proposed by Selling demands the same from the readers as well his conversation partners. Therefore, easy access to arguments of this work might be limited to experts in the field. But the scope of its implications certainly extends to pastoral practice, church life, and moral reasoning in general. What this paper has not done is refute any claims of this work; rather, one aspect of it has been embellished, namely, a goal-oriented ethical approach, so as to make it more perceptible and practicable in concrete.

This paper proposes that a goal-oriented moral approach is to be reinforced by four methodological pillars such as openness to human sciences, conversation among narratives, a theological frame for ethical goal setting, and non-discursive reasoning. Naturally, this raises the question of what superstructure these four pillars can together keep in focus as one sets his/her own ethical goals. This process cannot be served by any blind technique or an overarching framework, but it would demand the goal-setting person to sensitize him-/herself to these vital areas. It depends very much on the moral sensitivity of the goal-setting person. The goal-setting person is thus required to integrate the informational, affective, and motivational elements contained in moral reasoning and implied by the four pillars. As one becomes perceptive to these four methodological pillars, overcoming possible cognitive biases and affective blinders, his/her goal-oriented moral approach becomes less fallible.

Conflicts of Interest: The author declares no conflict of interest.

\section{References}

Aristotle. 1965. History of Animals. Translated by A. L. Peck. Harvard: Harvard University Press.

Christie, Dolores L. 1990. Adequately Considered: An American Perspective on Louis Janssens' Personalist Morals. Louvain Theological \& Pastoral Monographs, 4. Leven: Peters.

Farley, Margaret A. 2011. A Framework for Moral Discernment. In Catholic Theological Ethics Past, Present, and Future: The Trento Conference. Edited by James F. Keenan. Bangalore: TPI.

Gaziaux, Éric. 2011. In What Sense is Moral Theology Rational? In Catholic Theological Ethics Past, Present, and Future: The Trento Conference. Edited by James F. Keenan. Bangalore: TPI.

Hefner, Philip. 2003. Religion in the Context of Culture, Theology and Global Ethics. Zygon 38: 185-95. [CrossRef] Hume, David. 1968. Treatise of Human Nature. Edited by Lewis Amherst Selby-Bigge. Oxford: Clarendon, III.2.5. 
Illathuparampil, Mathew. 2009. Technology and Ethical Ambiguity. New Delhi: Global Vision Publishing House. Janssens, Louis. 1980. Artificial Insemination: Ethical Considerations. Louvain Studies 8: 3-29.

Selling, Joseph A. 2016. Reframing Catholic Theological Ethics. Oxford: Oxford University Press.

Smith, Adam. 1976. The Theory of Moral Sentiments. Edited by A. L. Macfie and D. D. Raphael. Oxford: Oxford University Press. 